\title{
The Effects of Customers' Bargaining Power on Capital Expenditure and Earnings Management: Evidence from Taiwan
}

\author{
Shieh-Liang Chen ${ }^{1} \&$ Li-Yu Chen ${ }^{2}$ \\ ${ }^{1}$ Department of Business Administration, Asia University, Taichung 41354, Taiwan \\ ${ }^{2}$ Master of Science Accounting, University of Arizona, AZ 85721, USA \\ Correspondence: Shieh-Liang Chen, Department of Business Administration, Asia University, Taichung, Taiwan.
}

Received: May 20, 2016

Accepted: June 16, 2016

Online Published: June 21, 2016

doi:10.5430/afr.v5n3p12

URL: http://dx.doi.org/10.5430/afr.v5n3p12

\begin{abstract}
This paper examines the effects of the suppliers-customers relationship on a company's earnings management and the effects of accrual-based and real activities earnings management on the capital expenditure of a company. This paper further examines the influence of the bargaining power of major customers on earnings management and how this bargaining power intervenes in the relationship between capital expenditure and earnings management.

When the bargaining power of major consumers is measured by the HHI index, the result shows that the higher the capital expenditure of a company, the greater the company's accrual earnings management. If the bargaining power of major customers is measured by the thresholds of 5\% and $10 \%$ of sales percentage, the higher the capital expenditure, the greater the real earnings management. The stronger the bargaining power of major customers, the larger the real activities and accrual-based earnings management of the company. Moreover, companies' capital expenditure and earnings management present a causal relationship. The bargaining power plays an important role in the relationship between earnings management and capital expenditure.
\end{abstract}

Keywords: Bargaining power, Customer concentration, Capital expenditure, Accrual-based earnings management, Real earnings management

\section{Introduction}

Selecting the most appropriate and the most reliable suppliers is one of the biggest challenges for companies across different industries (Riasi, 2015). The choice of reliable long-term suppliers is closely connected to the level of firms' loyalty to their suppliers and affects the cost of raw materials that they can obtain from their suppliers (Ansari \& Riasi, 2016). Companies tend to concentrate their strategic efforts on some selected partners in order to ensure cooperation, nurture innovations, and boost product quality. According to Banerjee, Dasgupta, and Kim (2008), a supplier may be more concerned with multi-year maintenance contracted revenues, whilst a customer may be worried about whether a supplier is able to provide high quality components, products, or services on a continuous basis. Long-term cooperative relationships are mostly implicit contracts that create benefits and cost advantages for suppliers. Although the upstream-downstream relationship is growing and getting important, limited literatures address how the costs and benefits of such relationships affect the financial policies of companies. Accordingly, this paper is motivated to fill up this gap.

Transactions in the input and output markets may involve investments in relationships with suppliers and customers. As these investments belong to specific firms, the value exchanged between suppliers and customers hinges on the future prospects of these commercial relationships. The perspectives of commercial relationships may influence stakeholders' incentives to invest in these relationships. Similar to the covenants between companies and creditors, contracts between suppliers and customers may also be complicated by the agency problem resulting from information asymmetry. If a company experiences financial distress or exits from a market, its suppliers may suffer from higher production costs due to the default or the inability to pay its obligations. On the other hand, customers will face with the problem of asymmetry information as a consequence of the company's performance. Previous literature indicates that information asymmetry between managers and outside investors is associated with company's investment efficiency (Bushman and Smith, 2001; Healy and Palepu, 2001; Lambert, Leuz, and Verrecchia, 2007). In addition, the capital expenditure is a major decision and requires greater capital in a company. Biddle and Hilary (2006) also suggest that firms with lower quality financial reporting have inefficient investments. 
This paper focuses on the issue of the capital expenditure of company (as the supplier).

While there is extensive literature on the motivations of earnings management in the capital market, few studies examine the role of suppliers and customers in the context of financial reporting decisions. Bowen, DuCharme, and Shores (1995) argue that the implicit requirements of stakeholders affect a company's choice of accounting methods to boost net incomes. In other words, stakeholders have an influence on accounting policies. According to Graham, Harvey, and Rajgopal (2005), most CFOs state that if earnings management helps companies to influence non-financial stakeholders, the specific relationship with suppliers and customers also affects decisions over earnings management.

There are two types of earnings management: accrual-based and real-activities. Accrual-based earnings management refers to the leverage of the flexibility in choice of accounting principles to manipulate reported earnings. This results from the selection of accounting methods that affect accounting earnings but not economic substance. Real activities earnings management refers to the establishment of actual transactions (i.e., R\&D expense cuts) with the aim of influencing the real performance or economic substance of the company. This method is likely to be detrimental to the firm's value, as current earnings may rise, while future cash flows typically decline. Dechow, Kothari, and Watts (1998) first establish an empirical model for real activities earnings management; their examples include the use of price discounts to temporarily boost sale revenues, overproduction to reduce cost of goods sold per unit, and reduction in discretionary expenses. Graham, Harvey, and Rajgopal (2005) suggest that managers prefer real activities over accrual-based earnings managements. Although real activities approach leads to more serious economic consequences, it is less likely to be detected by auditors or competent authorities. Roychowdhury (2006) indicates that real activities earnings management is deemed to be a deviation from normal operations in order to meet the earnings' threshold. In contrast with accrual-based earnings management, real activities method may influence cash flows. Barton (2001) and Lin, Radhakrishnan, and Su (2006) argue that companies often use more than two earnings management tools simultaneously.

Most literatures use discretionary or abnormal accruals to measure earnings management, while few researchers discuss real activities earnings management. Since different earnings management tools have different cost and benefit profiles, the characteristics of the different tools are only considered for decisions over earnings management. Therefore, this paper uses real activities and accrual-based earnings management to measure accounting quality and attempts to validate the determinants of earnings management in the context of the relationships with suppliers and customers. We first examine whether the relationships with suppliers and customers affect the degree of earnings management. Second, this paper analyzes whether accrual-based and real activities earnings managements affect capital expenditure under considering the relationships with suppliers and customers.

On the other hand, Hui, Klasa, and Yeung (2012) argue that if suppliers or customers boast greater bargaining power, then companies in either side will recognize losses at a faster pace. Watts and Zimmerman (1986) and Watts (2003a, 2003b) suggest that creditors often have bargaining advantages over firms because they determine borrowing terms. If the firm adopts more conservative accounting policies, it can help to reduce creditors' risks, which in turn enables the firm to obtain a lower interest rate on loans. This statement is also valid when accountants have stronger bargaining power. For instance, Basu (2001) finds that the Big Eight audit firms hold greater bargaining power than Non-Big Eight audit firms. Therefore, companies audited by the Big Eight show stronger accounting conservatism. This study considers the influence of the bargaining power of major customers on the earnings management of a company (as the supplier), and the moderating role played by bargaining power in the correlation between capital expenditure and earnings management.

The findings indicate that when the bargaining power of major consumers is measured by the HHI index, the higher the capital expenditure of a company, the greater the company's accrual earnings management. If the bargaining power of major customers is measured at the thresholds of $5 \%$ and $10 \%$ of sales percentage, the higher the capital expenditure, the greater the real activities earnings management. Moreover, the stronger the bargaining power of major customers, the larger the real activities and accrual-based earnings management of a company. Under considering the causal relationship between capital expenditure and earnings management, the evidence shows that for both earnings management methods, the greater the previous earnings management, the higher the current capital expenditure; the higher the current capital expenditure, the greater the current earnings management. Finally, the bargaining power of major customers affects the relationship between capital expenditure and both earnings management methods of the company. The bargaining power plays an important role in the relationship between earnings management and capital expenditure.

Hui, Klasa, and Yeung (2012) find that if firms' suppliers or customers have greater bargaining power, they 
recognize losses more quickly; that is, firms have higher accounting conservatism. Itzkowitz (2013) suggests that if a customer accounts for a high sales ratio of a supplier, the customer's operating loss perhaps cause the financial crisis of the supplier. However, above studies do not focus the role of earnings management in the relationship between suppliers and customers. McNichols and Stubben (2008) examine whether firms manipulating their financial reporting make suboptimal investment decisions, but they do not focus the effect of the suppliers-customers relationship on firm's capital decision. The contribution of our paper is to fill the literature gaps about the role of accounting information in the suppliers-customers relationship.

The remainder of the paper is organized as follows. Section 2 discusses prior literature and develops the hypotheses. Section 3 discusses the research design and Section 4 presents the results of the empirical tests. Section 5 concludes the paper.

\section{Literature Review and Hypotheses Development}

Francis, LaFond, Olsson, and Schipper (2005) and Aboody, Hughes, and Liu (2005) use the quality of accounting earnings as a proxy for information risk, and indicate a correlation between earnings quality and expected returns. Rajgopal and Venkatachalam (2011) posit that a step-up in earnings management compromises the accuracy of earnings quality. However, some scholars have proposed the opposite argument. According to Watts and Zimmerman (1986), if investors are able to detect earnings management, then they will be able to gain additional information. Subramanyam (1996) argues that discretionary accruals have a positive value and finds a positive relationship between discretionary accruals and returns during the same period and a predictive power of discretionary accruals on future profitability and dividend changes. Hence, managerial discretion can improve earnings informativeness. Badertscher, Collins, and Lys (2008) suggest that accruals may be accretive or dilutive to the informativeness implied by future cash flows, which depends on the motivation for earnings management, i.e., whether it is for speculation or for informativeness purposes.

Transactions with suppliers and customers often incorporate specific relational investments and such specific investments are company specific, and therefore, the investment yields a lower value outside of these relationships. The value of specific relational investments to suppliers and customers depends on the future prospects of companies, as the future size of transactions depends on the company's outlook. If the prospects are bright, then the expected returns on investments will be high for suppliers and customers. Information asymmetry between managers and external providers of capital causes adverse selection and moral hazards, both of which affect investment efficiency. Under adverse selection, managers are better informed than investors about a firm's true value of assets and the growth opportunity. Doyle, Ge, and McVay (2007) indicate that compared to controlled samples, companies with poor internal control yield poor quality in financing reporting. Ashbaugh-Skaife, Collins, Kinney, and LaFond (2009) and Dhaliwal, Hogan, Trezevant, and Wilkins (2011) argue that, compared to a controlled sample, companies with poor internal control pay higher capital costs for financing.

Prior literature indicated that managers are motivated to manage earnings for initial public offerings (IPOs), seasoned equity offerings (SEOs), issue convertible debts, or take out long-term loans from banks, in an attempt to issue shares at a high price or reduce the cost of debt. This study expects that, in the presence of significant information asymmetry between companies/managers and suppliers/customers, companies/managers have an incentive to manage earnings to attract suppliers/customers as long-term partners, in order to thereby raise external funds and increase capital investments.

Existing literature focuses on discretionary or abnormal accruals when examining earnings management methods, while recent studies tend to focus on real activities earnings management. Cohen and Zarowin (2010) indicate that real activities earnings management causes more negative effects to firm performances than accrual-based method. In practice, companies often consider the characteristics of different earnings management tools and are likely to engage in the use of different tools of earnings management. Therefore, we develop the following hypotheses:

H1a: The higher the capital expenditure of a company in current period, the greater the accrual-based earnings management.

H1b: The higher the capital expenditure of a company in current period, the greater the real activities earnings management.

The presence of major customers depends on whether any customers account for a high percentage of sales. The higher a percentage a customer accounts for, the greater bargaining power this customer has regarding part or all of the transaction terms. Meanwhile, Watts and Zimmerman (1986) argue that creditors usually have stronger bargaining power because they determine loan covenants and dictate conservative accounting policies, and thus 
reduce their loan costs. It is also applicable to the situation where auditors have bargaining power. Basu (2001) indicates that Big Eight firms have greater bargaining power in terms of auditors' fees than non-Big Eight firms because those companies audited by Big Eight firms tend to be conservative. Hui, Klasa, and Yeung (2012) find that there is a positive correlation between accounting conservatism and the bargaining power of customers and suppliers.

Regarding the correlation between equity financing and earnings management, DuCharme, Malatesta, and Sefcik (2004) suggest that companies are likely to report positive abnormal accruals during stock issuances; however, these accruals will turn negative after issuances. Cohen and Zarowin (2010) contend that real activities earnings management employed during SEOs causes a more drastic decline in firm performance after SEOs than accrual-based earnings management. In other words, what goes around comes around. Accruals will reverse and real activities earnings management will lead to future performance deterioration. In terms of the correlation between debt financing and earnings management, Chou, Wang, Chen, and Tsai (2009) suggest that companies resort to discretionary accruals to boost reported earnings before the issue of convertible debts. As a result, performance worsening occurs five years after the issuance.

We expect that major customers have greater bargaining power than other customers and that they make a very important contribution of revenue for the company. The greater the bargaining power customers have, the greater the necessity for suppliers to window-dress their financial statements with earnings management. Therefore, the following hypothesis is developed:

H2a: The greater the bargaining powers of major customers in current period, the larger the accrual-based earnings management of a company.

Hui, Klasa, and Yeung (2012) find that the stronger the bargaining power of suppliers or customers, the faster a company becomes to recognize bad news over good news, meaning that the bargaining power of suppliers or customers affects a company's accounting conservatism. Graham, Harvey, and Rajgopal (2005) argue that managers therefore prefer real activities earnings management to accrual-based method. Although real activities earnings management causes more adverse economic consequences, it is less likely to be detected by auditors or regulators. Roychowdhury (2006) posits that real activities earnings management is deemed to be a deviation from the normal management activities of a company, with the purpose of meeting a certain earnings threshold. Hence, we expect that a company will engage in real activities earnings management in order to enhance the negotiations advantage of the company with its main customers and therefore, this study develops the following hypothesis:

$\mathrm{H} 2 \mathrm{~b}$ : The greater the bargaining powers of the major customers in current period, the larger the real activities earnings management of a company.

Prior evidence suggested that information asymmetry and agency conflicts between managers and outside investors are associated with real investment efficiency (Bushman and Smith, 2001; Healy and Palepu, 2001; Lambert, Leuz, and Verrecchia, 2007). Biddle and Hilary (2006) show that firms with a lower quality of financial reporting exhibit inefficient investments. Moreover, Hui, Klasa, and Yeung (2012) find a positive association between the accounting conservatism of a supplier and the bargaining power of the customer; that is, the bargaining power of customers affects the accounting conservatism of the company. Hence, this paper expects that the bargaining power of a company's main customers will affect the relationship between capital expenditure and earnings management of company and therefore, the following hypotheses are developed:

H3a: The bargaining power of major customers will affect the relationship between capital expenditure and accrual-based earnings management of a company.

H3b: The bargaining power of major customers will affect the relationship between capital expenditure and real activities earnings management of a company.

Suppliers and customers have a vested interest in the future prospects of a company, as their benefits are built upon transactions with the company. As the perceptions of suppliers and customers regarding the incentives provided by the company are subject to its financial position, the company is able to achieve profitability by creating a good financial profile. Barton (2001) and Lin, Radhakrishnan, and Su (2006) indicate that companies often employ two or more earnings management tools to make their financial reports more attractive. In fact, some companies often engage in earnings management for window-dressing financial reports before making financing or investment decisions, hoping to reduce the capital costs of financing or raise funds for needs of capital expenditure. We expect that the greater the previous earnings management, the higher the current capital expenditure; the greater the current capital expenditure, the larger the current earnings management. This paper develops the following hypothesis:

H4: There is a causal relationship between capital expenditure and earnings management. 


\section{Research Design}

\subsection{Data}

The variable data of the sampled companies is for the period of 2007 2013. However, the data for cash flow volatility variables has to go back two years before this time, and hence, the sampling period of certain variables is from 2005 to 2013 , totaling nine years.

The selected sample companies are all listed companies and OTC companies on the Taiwan Stock Exchange Corporation (TWSE). These sampled companies must have upstream/downstream relationships and their annual data must be available in the Taiwan Economic Journal (TEJ). Furthermore, the sampled companies must have complete data for one or two years in order to calculate cash flow volatility. After elimination of companies in the financial and insurance industries due to special accounting treatments, companies with missing data that prevents calculations, and companies with repeated annual data, this paper has a total of 19,157 observations.

\subsection{Empirical Models}

This study uses the ordinary least-squares (OLS) fixed effects regression to examine whether the higher the capital expenditure, the larger the earnings management; and whether the higher the bargaining power of major customers, the larger the earnings management of the company. The interaction term in the regression model aims to verify whether the bargaining power of major customers will affect the relationship between capital expenditure and both accrual-based and real activities earnings management of the company.

$$
\begin{aligned}
\text { EM }_{i t} & =a_{0}+a_{1} \text { CapitalExp }_{i t}+a_{2} \text { CusBarPow }_{i t}+a_{3} \text { CapitalExp }_{i t} \text { CusBarPow }_{i t} \\
& +a_{4} \text { MB }_{i t}+a_{5} \text { CFOStd }_{i t}+a_{6} \text { Leverage }_{i t}+a_{7} \text { Dividend }_{i t}+a_{8} \text { Default }_{i t} \\
& +a_{9} \text { OCF }_{i t}+\text { Industry }^{\text {Year }}+e_{i t}
\end{aligned}
$$

We also analyze the relationship between capital expenditure and earnings management. This paper adopts the following model (2) and above model (1) to perform simultaneous equation regressions to explore the causal relationship between those two. These two models seek to examine H4 regarding the relationship between capital expenditure and earnings management by examining whether the greater the earnings management in the previous period, the higher the capital expenditure in the current period; and whether the greater the capital expenditure in the current period, the bigger the earnings management in the current period.

$$
\begin{aligned}
\text { CapitalExp }_{i t} & =a_{0}+a_{1} \text { EM }_{i t-1}+a_{2} \text { CusBarPow }_{i t-1}+a_{3} \text { EM }_{i t-1} \text { CusBarPow }_{i t-1} \\
& +a_{4} \text { MB }_{i t}+a_{5} \text { CFOStd }_{i t}+a_{6} \text { Leverage }_{i t}+a_{7} \text { Dividend }_{i t}+a_{8} \text { Default }_{i t} \\
& +a_{9} \text { OCF }_{i t}+\text { Industry }^{\text {Iear }}+e_{i t}
\end{aligned}
$$

where $E M_{i t}$ is earnings management of company $i$ (supplier) in year $t$, EM1 is accrual-based earnings management and EM2 is real activities earnings management. CusBarPow ${ }_{i t}$ is bargaining power of major customers of company $i$ in year $t . M B_{i t}$ is market to book ratio of company $i$ in year $t$, measured by dividing the market price of the stock by its book value. CFOStd ${ }_{i t}$ is operating cash flows volatility of company $i$ in year $t$, measured by the standard deviation of three years' operating cash flows at years $t, t-1$, and $t-2$, where operating cash flows is deflated by total assets at the beginning of the year. Leverage $e_{i t}$ is financial leverage of company $i$ in year $t$, measured by the ratio of long-term debts to total assets. Dividend $d_{i t}$ is dividend of company $i$ in year $t$, a dummy variable for the dividend payout in the current year; 1 if yes and 0 if not. Default $R_{i t}$ is default risks of company $i$ in year $t . O C F_{i t}$ is operating cash flows of company $i$ in year $t$, which is operating cash flows deflated by total assets at the beginning of the year. CapitalExp $p_{i t}$ is capital expenditure of company $i$ in year $t$, measured by the change in net fixed assets (i.e., property, plant and equipment), plus the disposal of fixed assets in the current year, and then deflated by total assets at the beginning of the year.

\subsection{Measurement of Variables}

\subsubsection{Bargaining Power of Customers}

This paper follows Hui, Klasa, and Yeung (2012) and uses two proxies to measure the bargaining power of major customers.

\section{(1) Key Stakeholders}

If a customer accounts for a high sales ratio of a supplier, then this customer enjoys bargaining power over its suppliers. This paper uses two dummy variables to measure whether major customers have bargaining power. If the 
answer is yes, this means that they are key stakeholders (main customers) to suppliers. These two dummy variables are: (i) the variable is set as 1 if a customer's purchase accounts for at least $5 \%$ of the sales of a supplier, and 0 if not; (ii) the variable is set as 1 if a customer accounts for at least $10 \%$ of the sales of a supplier, and 0 if not.

\section{(2) Concentration}

The Herfindahl-Hirschman Index (HHI) is used to measure the concentration of major customers. Its calculation is $\mathrm{HHI}=\sum_{i=1}^{\mathrm{n}}\left(X_{i} / X\right)^{2}$, where $X=$ total net sales of a company (supplier) and $X_{i}=$ net sales of a company to customer $i$, and $n=$ the number of major customers of a company's sales. The criterion of concentration of a company's sales based on the Taiwan Economic Journal database is: an HHI of 0.3 indicates a high concentration, an HHI of 0.18 0.3 indicates a medium-to-high concentration, and 0.1 or below indicates completion diversification.

\subsubsection{Accrual-based Earnings Management (EM1)}

This paper follows Rajgopal and Venkatachalam (2011) to measure accrual-based earnings management and the model specification is as follows.

$$
\frac{T C A_{i t}}{\text { Assets }_{i t-1}}=d_{0}+d_{1} \frac{C F O_{i t-1}}{\text { Assets }_{i t-1}}+d_{2} \frac{C F O_{i t}}{\text { Assets }_{i t-1}}+d_{3} \frac{C F O_{i t+1}}{\text { Assets }_{i t-1}}+d_{4} \frac{\Delta R E V_{i t}}{\text { Assets }_{i t-1}}+d_{5} \frac{P P E_{i t}}{\text { Assets }_{i t-1}}+e_{i t}
$$

where $T C A$ denotes total current accruals, which is $\triangle C A-\triangle C L-\triangle C a s h+\triangle S T D E B T . \triangle C A$ denotes the change in current assets, $\triangle C L$ denotes the change in current liabilities, $\triangle$ Cash denotes the change in cash balance, $\triangle S T D E B T$ denotes the change in the current portion of long-term debts. $C F O$ denotes the cash flow from operations. Assets is total assets. $\triangle R E V$ denotes the change in sales revenues. PPE denotes the gross value of property, plant and equipment. The residual in Equation (3) is abnormal accruals. This study uses Equation (3) for the annual estimate of each company and the samples includes at least 20 companies for each industry during the $t$ period (refer to Fama and French, 1997). The company-specific residual (residual in Equation (3)) measures the quality of financial reporting of a company. The absolute value of the residual in the regression is referred to as the proxy variable for poor quality financing reporting of a company. We treat a larger absolute value of residuals as an indication of poor account quality.

\subsubsection{Real Earnings Management (EM2)}

To measure our proxies for real activities manipulation, this paper follows the cross-sectional regression analysis of Cohen and Zarowin (2010) by measuring the levels of real transaction manipulations with the abnormal cash flow from operations $(A C F O)$, abnormal discretionary expenses (ADISX), and abnormal production costs (APROD). EM2 is calculated by the sum of $A C F O$ and $A D I S X$ multiplying by -1 and then adding APROD. The higher EM2 implies that the magnitude of real earnings management is greater. The measurements of these three real earnings management variables are as follows:

$A C F O$ represents the abnormal cash flow from operations, measured by the residuals in the following industry-year regression.

$$
\frac{\text { CFO }_{i t}}{\text { Assets }_{i t-1}}=b_{1} \frac{1}{\text { Assets }_{i t-1}}+b_{2} \frac{\text { SALES }_{i t}}{\text { Assets }_{i t-1}}+b_{3} \frac{\Delta S A L E S_{i t}}{\text { Assets }_{i t-1}}+\eta_{i t}
$$

where $C F O$ denotes cash flows from operations, Assets denotes total assets, SALES denotes net sales, and $\triangle S A L E S$ denotes the change in net sales.

$A P R O D$ represents the abnormal production costs, measured by the residuals in the following industry-year regressions.

$$
\begin{aligned}
& \frac{\operatorname{COGS}_{i t}}{\text { Assets }_{i t-1}}=f_{1} \frac{1}{\text { Assets }_{i t-1}}+f_{2} \frac{\operatorname{SALES~}_{i t}}{\text { Assets }_{i t-1}}+\varepsilon_{i t} \\
& \frac{\Delta I N V_{i t}}{\text { Assets }_{i t-1}}=g_{1} \frac{1}{\text { Assets }_{i t-1}}+g_{2} \frac{\Delta S A L E S_{i t}}{\text { Assets }_{i t-1}}+g_{3} \frac{\Delta \text { SALES }_{i t-1}}{\text { Assets }_{i t-1}}+\varepsilon_{i t}
\end{aligned}
$$


where COGS denotes cost of goods sold, $\triangle I N V$ denotes the changes of inventory, Assets denotes total assets, SALES denotes net sales, and $\triangle S A L E S$ denotes the change in net sales. APROD can be measured with the sum of error terms in Equation (5) and Equation (6).

ADISX represents the abnormal discretionary expenses, which is estimated using the residuals in the following industry-year regression.

$$
\frac{\operatorname{DISX}_{i t}}{\operatorname{Assets}_{i t-1}}=h_{1} \frac{1}{\text { Assets }_{i t-1}}+h_{2} \frac{\text { SALES }_{i t-1}}{\text { Assets }_{i t-1}}+e_{i t}
$$

where DISX is discretionary expenses during the year, defined as the sum of $\mathrm{R} \& \mathrm{D}$ expenses, advertising expenses, and administrative expenses. Assets denotes total assets and SALES denotes net sales.

\subsubsection{Accounting Conservatism (Conservatism)}

We follow Hui, Klasa, and Yeung (2012) to measure accounting conservatism. This paper first measure the timeline of earnings based on Basu (1997), which is the timeline that a company recognizes bad news. The estimated model is as follows:

$$
X_{i t} / P_{i t-1}=a_{0}+a_{1} D R_{i t}+a_{2} R E T_{i t}+a_{3} D R_{i t} \times R E T_{i t}+e_{i t}
$$

where $X_{i t}$ is earnings per share at the year-end, $P_{i t-1}$ is stock price at the prior year-end, $R E T_{i t}$ is stock return at the year-end. $D R$ is a dummy variable, we set to $D R=1$ if the company has bad news, that is, $R E T<1$, and $D R=0$ if $R E T>1$. If the company recognizes bad news early or delays the recognition of good news, we obtain $a_{3}>0$ in Equation (8).

Next, using a rolling-window method, this paper adopts the current year and prior 6 years, totaling 7 years data to perform firm-specific time-series regressions and estimate the coefficients of each year. Finally, following Hui, Klasa, and Yeung (2012), the asymmetric timeline of earnings is measured by $\left(a_{2}+a_{3}\right) / a_{2}$. This ratio reflects a company's timeline to recognize bad news relative to the recognition of good news, which is similar to timely response of stock returns.

\section{Empirical Results}

\subsection{Sample Analysis}

This paper measures accrual-based earnings management (EM1) and real activities earnings management (EM2) to examine whether accrual-based earnings management and real activities manipulation are subject to the influence of the company's capital expenditure and customers' bargaining power. Table 1 summarizes the descriptive statistics of all variables in the regression models. According to Table 1, the mean of accrual-based earnings management EM1 is 0.0564 , maximum value being 0.3198 , and minimum value being 0.0008 . These indicate a significant difference in the degree of accrual-based earnings management from one company to another. The mean of real activities earnings management EM2 is -0.1767 , maximum being 0.5641 , and minimum being -0.9892 . These also suggest obvious differences in the degree of real activities earnings management between companies.

We define the bargaining power of major customers as CusBarPow ${ }_{i t}$, measured by major customer's purchases over $5 \%$ of the sales of the company and a major customer's purchase over $10 \%$ of total sales of a supplier, and the sales' concentration of the company, as indicated by HHI. In Table 1, the mean of the Herfindahl-Hirschman Index is 0.1120 , maximum being 0.9880 , and minimum being 0.0000 . An HHI of 0.3 , as calculated by the Taiwan Economic Journal, indicates a high concentration, an $\mathrm{HHI}$ of $0.18 \sim 0.3$ indicates a medium-to-high concentration, and 0.1 or below indicates completion diversification. These results show that major customers enjoy greater bargaining power and are key stakeholders of the company.

On the other hand, Table 2 shows the correlation coefficients between two variables in the regression models. In Table 1, all the pairwise correlation coefficients are lower than 0.7 and therefore, there is no collinearity between any two variables. 
Table 1. Descriptive statistics

\begin{tabular}{llllll}
\hline & Mean & Std. Dev. & Medium & Minimum & Maximum \\
\hline EM1 & 0.0564 & 0.0582 & 0.0390 & 0.0008 & 0.3198 \\
EM2 & -0.1767 & 0.2565 & -0.1431 & -0.9892 & 0.5641 \\
CapitalExp & -0.0263 & 0.0444 & -0.0084 & -0.2471 & 0.0000 \\
CusBarPow 5\% & 0.8400 & 0.3666 & 1.0000 & 0.0000 & 1.0000 \\
CusBarPow 10\% & 0.7231 & 0.4475 & 1.0000 & 0.0000 & 1.0000 \\
CusBarPow HHI & 0.1120 & 0.1327 & 0.0689 & 0.0000 & 0.9880 \\
MB & 1.5008 & 1.0074 & 1.2200 & 0.3200 & 5.8800 \\
CFOStd & 0.0725 & 0.0649 & 0.0549 & 0.0038 & 0.3817 \\
Leverage & 0.3451 & 0.1646 & 0.3353 & 0.0322 & 0.7392 \\
Dividend & 0.6371 & 0.4808 & 1.0000 & 0.0000 & 1.0000 \\
DefaultR & 0.6677 & 0.4711 & 1.0000 & 0.0000 & 1.0000 \\
OCF & 0.0597 & 0.1081 & 0.0530 & -0.3116 & 0.3642 \\
\hline
\end{tabular}

The number of observations of all variables is 19,157 excluding CusBarPow HHI is 5,159.

Variable Definitions: EM1 denotes accrual-based earnings management. EM2 denotes real activities earnings management. CapitalExp denotes capital expenditure. CusBarPow 5\% of sales denotes the bargaining power of major customers, which is measured by the purchases of major customers that are larger than 5\% of the firm's total sales (as the supplier). CusBarPow $10 \%$ of sales denotes the bargaining power of major customers, which is measured by the purchases of major customers that are larger than $10 \%$ of the firm's total sales (as the supplier). CusBarPow HHI denotes the bargaining power of major customers, which is measured by HHI. MB denotes market to book ratio. CFOStd denotes the volatility of operating cash flows. Leverage denotes financial leverage. Dividend denotes cash dividends. DefaultR denotes default risk. OCF denotes operating cash flows.

Table 2. Pearson correlation analysis

\begin{tabular}{|c|c|c|c|c|c|c|c|c|c|c|c|}
\hline & EM1 & EM2 & CapitalExp & $\begin{array}{l}\text { CusBarPow } \\
5 \%\end{array}$ & $\begin{array}{l}\text { CusBarPow } \\
10 \%\end{array}$ & MB & CFOStd & Leverage & Dividend & DefaultR & OCF \\
\hline EM1 & 1.000 & & & & & & & & & & \\
\hline EM2 & $\begin{array}{l}0.0445 \\
(0.000)\end{array}$ & 1.000 & & & & & & & & & \\
\hline CapitalExp & $\begin{array}{l}0.0013 \\
(0.862)\end{array}$ & $\begin{array}{l}0.1619 \\
(0.000)\end{array}$ & 1.000 & & & & & & & & \\
\hline CusBarPow 5\% & $\begin{array}{l}0.0002 \\
(0.975)\end{array}$ & $\begin{array}{l}-0.0336 \\
(0.000)\end{array}$ & $\begin{array}{l}-0.0081 \\
(0.260)\end{array}$ & 1.000 & & & & & & & \\
\hline CusBarPow $10 \%$ & $\begin{array}{l}0.0116 \\
(0.109)\end{array}$ & $\begin{array}{l}-0.0454 \\
(0.000)\end{array}$ & $\begin{array}{l}0.0000 \\
(0.999)\end{array}$ & $\begin{array}{l}0.7052 \\
(0.000)\end{array}$ & 1.000 & & & & & & \\
\hline MB & $\begin{array}{l}0.2129 \\
(0.000)\end{array}$ & $\begin{array}{l}-0.3594 \\
(0.000)\end{array}$ & $\begin{array}{l}-0.1353 \\
(0.000)\end{array}$ & $\begin{array}{l}0.0027 \\
(0.711)\end{array}$ & $\begin{array}{l}0.0227 \\
(0.002)\end{array}$ & 1.000 & & & & & \\
\hline CFOStd & $\begin{array}{l}0.1811 \\
(0.000)\end{array}$ & $\begin{array}{l}0.0621 \\
(0.000)\end{array}$ & $\begin{array}{l}0.0073 \\
(0.312)\end{array}$ & $\begin{array}{l}-0.0170 \\
(0.019)\end{array}$ & $\begin{array}{l}0.0081 \\
(0.260)\end{array}$ & $\begin{array}{l}0.1253 \\
(0.000)\end{array}$ & 1.000 & & & & \\
\hline Leverage & $\begin{array}{l}0.0262 \\
(0.003)\end{array}$ & $\begin{array}{l}0.2702 \\
(0.000)\end{array}$ & $\begin{array}{l}-0.0349 \\
(0.000)\end{array}$ & $\begin{array}{l}-0.0172 \\
(0.017)\end{array}$ & $\begin{array}{l}-0.0294 \\
(0.000)\end{array}$ & $\begin{array}{l}-0.0438 \\
(0.000)\end{array}$ & $\begin{array}{l}0.1254 \\
(0.000)\end{array}$ & 1.000 & & & \\
\hline Dividend & $\begin{array}{l}-0.2226 \\
(0.000)\end{array}$ & $\begin{array}{l}-0.2330 \\
(0.000)\end{array}$ & $\begin{array}{l}-0.0634 \\
(0.000)\end{array}$ & $\begin{array}{l}0.0298 \\
(0.000)\end{array}$ & $\begin{array}{l}0.0514 \\
(0.000)\end{array}$ & $\begin{array}{l}0.0822 \\
(0.000)\end{array}$ & $\begin{array}{l}-0.0333 \\
(0.000)\end{array}$ & $\begin{array}{l}-0.0945 \\
(0.000)\end{array}$ & 1.000 & & \\
\hline DefaultR & $\begin{array}{l}-0.2318 \\
(0.000)\end{array}$ & $\begin{array}{l}-0.2492 \\
(0.000)\end{array}$ & $\begin{array}{l}-0.0668 \\
(0.000)\end{array}$ & $\begin{array}{l}0.0367 \\
(0.000)\end{array}$ & $\begin{array}{l}0.0669 \\
(0.000)\end{array}$ & $\begin{array}{l}0.1218 \\
(0.000)\end{array}$ & $\begin{array}{l}-0.0738 \\
(0.000)\end{array}$ & $\begin{array}{l}-0.1909 \\
(0.000)\end{array}$ & $\begin{array}{l}0.5791 \\
(0.000)\end{array}$ & 1.000 & \\
\hline $\mathrm{OCF}$ & $\begin{array}{l}-0.1660 \\
(0.000)\end{array}$ & $\begin{array}{l}-0.6799 \\
(0.000)\end{array}$ & $\begin{array}{l}-0.1981 \\
(0.000)\end{array}$ & $\begin{array}{l}0.0366 \\
(0.000)\end{array}$ & $\begin{array}{l}0.0503 \\
(0.000)\end{array}$ & $\begin{array}{l}0.1826 \\
(0.000)\end{array}$ & $\begin{array}{l}-0.1179 \\
(0.000)\end{array}$ & $\begin{array}{l}-0.1914 \\
(0.000)\end{array}$ & $\begin{array}{l}0.3109 \\
(0.000)\end{array}$ & $\begin{array}{l}0.3393 \\
(0.000)\end{array}$ & 1.000 \\
\hline
\end{tabular}

Variable Definitions:

EM1 denotes accrual-based earnings management. EM2 denotes real activities earnings management. CapitalExp denotes capital expenditure. CusBarPow $5 \%$ of sales denotes the bargaining power of major 
customers, which is measured by the purchases of major customers that are larger than 5\% of the firm's total sales (as the supplier). CusBarPow 10\% of sales denotes the bargaining power of major customers, which is measured by the purchases of major customers that are larger than $10 \%$ of the firm's total sales (as the supplier). MB denotes market to book ratio. CFOStd denotes the volatility of operating cash flows. Leverage denotes financial leverage. Dividend denotes cash dividends. DefaultR denotes default risk. OCF denotes operating cash flows.

\subsection{Impacts of Capital Expenditure and Bargaining Power on Earnings Management}

Table 3 shows the results of the OLS fixed effect regression that aims to validate H1 and H2. From Panel A in Table 3 , there is no correlation between a company's capital expenditure and accrual-based earnings management when the bargaining power of major customers is measured by sales revenues percentages. When the bargaining power of major consumers is measured by the HHI Index, there is a positive correlation between the company's capital expenditure and its accrual-based earnings management, supporting H1a. This evidence indicates that the higher the capital expenditure, the greater the accrual-based earnings management.

From Panel B in Table 3, there is a positive correlation between capital expenditure and real activities earnings management if the bargaining power of major customers is measured by the thresholds of $5 \%$ and $10 \%$, which is the percentage that the supplier sells to its customer (i.e., the purchase of the customer from the supplier). Hence, H1b is supported, indicating that the higher the capital expenditure, the greater the real activities earnings management.

In Panel A of Table 3, the bargaining power of major customers has a positive influence on accrual-based earnings management of a company, no matter whether such bargaining power is measured by the $10 \%$ threshold of contribution to the supplier's sales or the degree of sale concentration HHI, suggesting that the stronger the bargaining power of major customers, the greater the accrual-based earnings management of companies, supporting H2a. Panel B in Table 3 shows that real activities earnings management is positively related to sale concentration $\mathrm{HHI}$ but is unrelated to sales percentage proxy. The evidence of HHI supports H2b. Overall, our results support H2a and $\mathrm{H} 2 \mathrm{~b}$, that is, the stronger the bargaining power of major customers, the larger the accrual-based and real activities earnings management of the company.

According to Model 1c of Panel A, the interaction term of capital expenditure of a company and the bargaining power of its major customers is negatively related to the company's accrual-based earnings management when the bargaining power of major customers is measured by the HHI Index. This finding supports H3a that the bargaining power of major customers will affect the relationship between capital expenditure and accrual-based earnings management of a company. A possible reason for this is that the earnings management of a company is also influenced by corporate financing policy, financing costs, investment decision factors, or the bargaining power of major customers.

Moreover, from Models (2a) and (2b) in Panel B of Table 3, the evidence shows that the interaction term of capital expenditure of a company and bargaining power of major customers (as measured by a $5 \%$ or $10 \%$ thresholds of sales revenue) are negatively related to real activities earnings management. This finding implies that the bargaining power of major customers may affect the relationship between capital expenditure and real activities earnings management of the company, supporting $\mathrm{H} 3 \mathrm{~b}$. 
Table 3. Bargaining power, capital expenditure and earnings management

$$
\begin{aligned}
\mathrm{EM}_{i t} & =a_{0}+a_{1} \text { CapitalExp }_{i t}+a_{2} \text { CusBarPow }_{i t}+a_{3} \text { CapitalExp }_{i t} \text { CusBarPow }_{i t}+a_{4} \text { MB }_{i t} \\
& +a_{5} \text { CFOStd }_{i t}+a_{6} \text { Leverage }_{i t}+a_{7} \text { Dividend }_{i t}+a_{8} \text { Default }_{i t}+a_{9} \text { OCF }_{i t}+\text { Industry }+ \text { Year }+e_{i t}
\end{aligned}
$$

Panel A: Accrual-based earnings management

\begin{tabular}{lllllll}
\hline EM= Accrual-based & \multicolumn{2}{l}{ (1a) $5 \%$ of sales } & \multicolumn{2}{l}{ (1b) 10\% of sales } & (1c) HHI & \\
earnings management & Coefficient & $\mathrm{p}$-Value & Coefficient & $\mathrm{p}$-Value & Coefficient & p-Value \\
\hline CapitalExp & 0.0142 & 0.546 & -0.0089 & 0.623 & 0.0476 & 0.070 \\
CusBarPow & 0.0016 & 0.200 & 0.0033 & 0.001 & 0.0269 & 0.001 \\
CapitalExp*CusBarPow & -0.0256 & 0.310 & 0.0017 & 0.935 & -0.5530 & 0.016 \\
MB & 0.0156 & 0.000 & 0.0156 & 0.000 & 0.0147 & 0.000 \\
CFOStd & 0.1070 & 0.000 & 0.1070 & 0.000 & 0.1230 & 0.000 \\
Leverage & -0.0126 & 0.000 & -0.0126 & 0.000 & -0.0289 & 0.000 \\
Dividend & -0.0168 & 0.000 & -0.0168 & 0.000 & -0.0162 & 0.000 \\
DefaultR & -0.0162 & 0.000 & -0.0164 & 0.000 & -0.0162 & 0.000 \\
OCF & -0.0688 & 0.000 & -0.0690 & 0.000 & -0.0610 & 0.000 \\
Intercept & 0.0257 & 0.000 & 0.0250 & 0.000 & 0.0582 & 0.001 \\
Year and Industry & Included & & Included & & Included & \\
\hline No. of observations & 19157 & & 19157 & & 5159 & \\
$\mathrm{R}^{2}$ & 0.169 & 0.170 & & 0.179 & \\
F value (p value) & $117.0(0.000)$ & $117.1(0.000)$ & & $36.6(0.000)$ & \\
\hline
\end{tabular}

Panel B: Real activities earnings management

\begin{tabular}{lllllll}
\hline $\begin{array}{l}\text { EM= Real activities } \\
\text { earnings management }\end{array}$ & \multicolumn{2}{l}{ (2a) $5 \%$ of sales } & \multicolumn{2}{l}{ (2b) 10\% of sales } & (2c) HHI & \\
\hline CapitalExp & Coefficient & $\mathrm{p}$-Value & Coefficient & $\mathrm{p}$-Value & Coefficient & $\mathrm{p}$-Value \\
CusBarPow & 0.2230 & 0.034 & 0.1970 & 0.007 & -0.0008 & 0.993 \\
CapitalExp*CusBarPow & -0.0027 & 0.500 & -0.0013 & 0.683 & 0.0884 & 0.000 \\
MB & -0.0628 & 0.028 & -0.2440 & 0.002 & 0.0197 & 0.974 \\
CFOStd & 0.000 & -0.0629 & 0.000 & -0.0632 & 0.000 \\
Leverage & 0.1241 & 0.000 & 0.1242 & 0.000 & 0.1640 & 0.000 \\
Dividend & 0.1930 & 0.000 & 0.1930 & 0.000 & 0.2440 & 0.000 \\
DefaultR & -0.0052 & 0.078 & -0.0052 & 0.079 & 0.0109 & 0.065 \\
OCF & 0.0035 & 0.246 & 0.0033 & 0.270 & 0.0074 & 0.206 \\
Intercept & -1.4250 & 0.000 & -1.4260 & 0.000 & -1.3990 & 0.000 \\
Year and Industry & 0.1601 & 0.000 & 0.1591 & 0.000 & -0.0062 & 0.844 \\
\hline No. of observations & Included & & Included & & Included & \\
$\mathrm{R}^{2}$ & 19157 & & 19157 & & 5159 & \\
F value (p value) & $1409.8(0.000)$ & 0.598 & & 0.551 & \\
\hline
\end{tabular}

Variable Definitions: EM denotes accrual-based earnings management in Panel A. EM denotes real activities earnings management in Panel B. CapitalExp denotes capital expenditure. CusBarPow 5\% of sales denotes the bargaining power of major customers, which is measured by the purchases of major customers that are larger than $5 \%$ of the firm's total sales (as the supplier). CusBarPow $10 \%$ of sales denotes the bargaining power of major customers, which is measured by the purchases of major customers that are larger than $10 \%$ 
of the firm's total sales (as the supplier). CusBarPow HHI denotes the bargaining power of major customers, which is measured by HHI. MB denotes market to book ratio. CFOStd denotes the volatility of operating cash flows. Leverage denotes financial leverage. Dividend denotes cash dividends. DefaultR denotes default risk. OCF denotes operating cash flows.

\subsection{Relationship between Earnings Management and Capital Expenditure}

This paper further adopts simultaneous equation regression models to analyze whether earnings management in the previous period affects a company's capital expenditure in the current period, or whether capital expenditure in the current period affects a company's earnings management in the same period.

In Table 4, the findings indicate that the greater the accrual-based earnings management in the previous period, the higher the capital expenditure in the current period. Further, the greater the accrual-based earnings management and the stronger the bargaining power of major customers in the previous period, the lower the capital expenditure in the current period. On the other hand, we find that the higher the capital expenditure in the current period, the greater the accrual-based earnings management in the current period. Moreover, the bargaining power of major customers in the current period may affect the relationship between capital expenditure and accrual-based earnings management of a company in the current period. In sum, there is an interrelation between accrual-based earnings management and capital expenditure, and the evidence supports $\mathrm{H} 4$.

Table 5 shows whether a company's real activities earnings management in the previous period affects capital expenditure of the company in the current period, or whether capital expenditure in the current period affects real activities earnings management in the same period. The results of real activities earnings management are consistent with those in accrual-based method. That is, the greater the real activities earnings management in the previous period, the higher the capital expenditure in the current period. The greater the real activities earnings management and the stronger the bargaining power of major customers in the previous period, the lower the capital expenditure in the current period. On the other hand, higher capital expenditure in the current period results in greater real activities earnings management in the current period. The bargaining power of major customers in the current period may affect the relationship between capital expenditure and real activities earnings management of a company in the current period. There is therefore an interrelation between real activities earnings management and capital expenditure, supporting $\mathrm{H} 4$.

It is worth noting that, in Table 4, the finding shows that the stronger the bargaining powers of major customers in the current period, the smaller the company's accrual-based earnings management in the current period. Meanwhile, in Table 5, we find that the stronger the bargaining powers of major customers in the current period, the smaller the real activities earnings management in the current period. Differing from Table 3, the models in Tables 4 and 5 consider the causal relationship between earning management and capital expenditure. A possible reason for this result is that the influential factors of earnings management include corporate financing and investment decisions or the bargaining power of main customers. 
Table 4. Interrelation between capital expenditure and accrual-based earnings management

\begin{tabular}{|c|c|c|c|c|}
\hline \multicolumn{5}{|c|}{$\begin{aligned} \text { CapitalExp }_{i t}= & a_{0}+a_{1} \text { EM }_{i t-1}+a_{2} \text { CusBarPow }_{i t-1}+a_{3} \text { EM }_{i t-1} \text { CusBarPow }_{i t-1}+a_{4} \text { MB }_{i t}+a_{5} \text { CFOStd }_{i t} \\
& +a_{6} \text { Leverage }_{i t}+a_{7} \text { Dividend }_{i t}+a_{8} \text { Default }_{i t}+a_{9} \text { OCF }_{i t}+\text { Industry }_{\text {Year }}+e_{i t} \\
\text { EM }_{i t}= & a_{0}+a_{1} \text { CapitalExp }_{i t}+a_{2} \text { CusBarPow }_{i t}+a_{3} \text { CapitalExp }_{i t} \text { CusBarPow }_{i t}+a_{4} \text { MB }_{i t}+a_{5} \text { CFOStd }_{i t} \\
& +a_{6} \text { Leverage }_{i t}+a_{7} \text { Dividend }_{i t}+a_{8} \text { Default }_{i t}+a_{9} \text { OCF }_{i t}+\text { Industry }+ \text { Year }+e_{i t}\end{aligned}$} \\
\hline & \multicolumn{2}{|l|}{$5 \%$ of sales } & \multicolumn{2}{|l|}{$10 \%$ of sales } \\
\hline & Coefficient & p-Value & Coefficient & p-Value \\
\hline \multicolumn{5}{|c|}{ Dependent variable: CapitalExp } \\
\hline EM & 0.0725 & 0.003 & 0.0383 & 0.008 \\
\hline CusBarPow & 0.0024 & 0.214 & 0.0010 & 0.482 \\
\hline EM*CusBarPow & -0.0504 & 0.047 & -0.0162 & 0.317 \\
\hline MB & -0.0025 & 0.000 & -0.0025 & 0.000 \\
\hline CFOStd & -0.1310 & 0.000 & -0.1310 & 0.000 \\
\hline Leverage & -0.0181 & 0.000 & -0.0184 & 0.000 \\
\hline Dividend & 0.0051 & 0.000 & 0.0050 & 0.000 \\
\hline DefaultR & -0.0018 & 0.135 & -0.0018 & 0.122 \\
\hline OCF & -0.0916 & 0.000 & -0.0915 & 0.000 \\
\hline Intercept & 0.0040 & 0.445 & -0.1290 & 0.000 \\
\hline Year and Industry & Included & & Included & \\
\hline \multicolumn{5}{|l|}{ Dependent variable: EM } \\
\hline CapitalExp & 3.1590 & 0.054 & 2.9300 & 0.018 \\
\hline CusBarPow & -0.0766 & 0.060 & -0.0740 & 0.024 \\
\hline CapitalExp*CusBarPow & -3.1330 & 0.053 & -2.8690 & 0.019 \\
\hline MB & 0.0160 & 0.000 & 0.0167 & 0.000 \\
\hline CFOStd & 0.0849 & 0.000 & 0.0929 & 0.000 \\
\hline Leverage & -0.0088 & 0.113 & -0.0006 & 0.943 \\
\hline Dividend & -0.0248 & 0.000 & -0.0240 & 0.000 \\
\hline DefaultR & -0.0132 & 0.000 & -0.0124 & 0.000 \\
\hline OCF & -0.0203 & 0.289 & -0.0071 & 0.735 \\
\hline Intercept & 0.1160 & 0.001 & 0.1370 & 0.013 \\
\hline Year and Industry & Included & & Included & \\
\hline F value ( $\mathrm{p}$ value) & 101.2 & & $101.0(0.000$ & \\
\hline
\end{tabular}

Number of observations is 15,432. Variable Definitions: EM denotes accrual-based earnings management. CapitalExp denotes capital expenditure. CusBarPow 5\% of sales denotes the bargaining power of major customers, which is measured by the purchases of major customers that are larger than $5 \%$ of the firm's total sales (as the supplier). CusBarPow $10 \%$ of sales denotes the bargaining power of major customers, which is measured by the purchases of major customers that are larger than $10 \%$ of the firm's total sales. CusBarPow HHI denotes the bargaining power of major customers, which is measured by HHI. MB denotes market to book ratio. CFOStd denotes the volatility of operating cash flows. Leverage denotes financial leverage. Dividend denotes cash dividends. DefaultR denotes default risk. OCF denotes operating cash flows. 
Table 5. Interrelation between capital expenditure and real activities earnings management

\begin{tabular}{|c|c|c|c|c|}
\hline \multicolumn{5}{|c|}{ 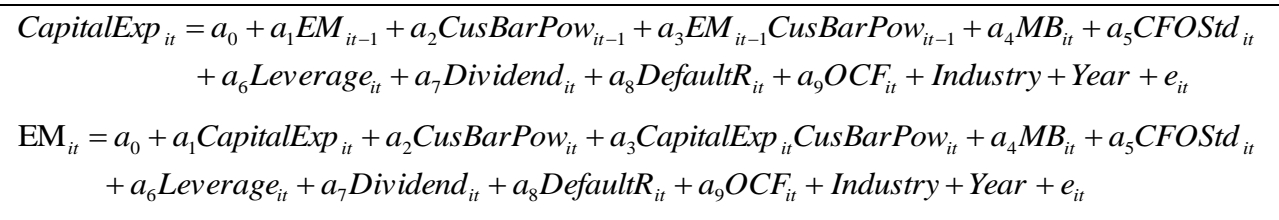 } \\
\hline & \multicolumn{2}{|l|}{$5 \%$ of sales } & \multicolumn{2}{|l|}{$10 \%$ of sales } \\
\hline & C0oefficient & p-Value & Coefficient & p-Value \\
\hline \multicolumn{5}{|c|}{ Dependent variable: CapitalExp } \\
\hline EM & 0.0314 & 0.000 & 0.0268 & 0.000 \\
\hline CusBarPow & -0.0016 & 0.275 & -0.0011 & 0.358 \\
\hline EM*CusBarPow & -0.0138 & 0.004 & -0.0095 & 0.008 \\
\hline MB & -0.0011 & 0.003 & -0.0011 & 0.003 \\
\hline CFOStd & -0.1390 & 0.000 & -0.1390 & 0.000 \\
\hline Leverage & -0.0251 & 0.000 & -0.0250 & 0.000 \\
\hline Dividend & 0.0061 & 0.000 & 0.0061 & 0.000 \\
\hline DefaultR & -0.0011 & 0.342 & -0.0011 & 0.349 \\
\hline OCF & -0.0895 & 0.000 & -0.0896 & 0.000 \\
\hline Intercept & -0.1270 & 0.000 & -0.1260 & 0.000 \\
\hline Year and Industry & Included & & Included & \\
\hline \multicolumn{5}{|l|}{ Dependent variable: EM } \\
\hline CapitalExp & 17.480 & 0.000 & 29.820 & 0.000 \\
\hline CusBarPow & -0.4290 & 0.000 & -0.7810 & 0.000 \\
\hline CapitalExp*CusBarPow & -17.220 & 0.000 & -29.270 & 0.000 \\
\hline MB & -0.0292 & 0.000 & -0.0105 & 0.127 \\
\hline CFOStd & 0.3970 & 0.000 & 0.6110 & 0.000 \\
\hline Leverage & 0.2320 & 0.000 & 0.3420 & 0.000 \\
\hline Dividend & -0.0440 & 0.000 & -0.0688 & 0.000 \\
\hline DefaultR & 0.0224 & 0.009 & 0.0447 & 0.014 \\
\hline $\mathrm{OCF}$ & -1.4420 & 0.000 & -1.1580 & 0.000 \\
\hline Intercept & 0.5490 & 0.000 & 1.3450 & 0.000 \\
\hline Year and Industry & Included & & Included & \\
\hline F value ( $\mathrm{p}$ value) & $110.2(0.000)$ & & $1(0.000)$ & \\
\hline
\end{tabular}

Number of observations is 15,432. Variable Definitions: EM denotes real activities earnings management. CapitalExp denotes capital expenditure. CusBarPow 5\% of sales denotes the bargaining power of major customers, which is measured by the purchases of major customers that are larger than $5 \%$ of the firm's total sales (as the supplier). CusBarPow $10 \%$ of sales denotes the bargaining power of major customers, which is measured by the purchases of major customers that are larger than $10 \%$ of the firm's total sales (as the supplier). CusBarPow HHI denotes the bargaining power of major customers, which is measured by HHI. MB denotes market to book ratio. CFOStd denotes the volatility of operating cash flows. Leverage denotes financial leverage. Dividend denotes cash dividends. DefaultR denotes default risk. OCF denotes operating cash flows.

\subsection{Robustness Check}

Basu (1997) and Watts (2003) indicate that relative to other stakeholders, managers have an incentive through their information advantage to obtain bad news, which is faster than good news. Watts and Zimmerman (1990) suggest 
that a company, which is a debt-holder owning bargaining advantage and has more conservative accounting, can set loan terms and obtain lower loan interest rates. When auditors have a bargaining advantage, the above result is supported. For example, Basu (2001) finds that the Big-8 auditors have a greater bargaining advantage than non-Big-8 auditors, such that firms audited by the Big Eight audit firms are more conservative. Hui, Klasa, and Yeung (2012) indicate that accounting conservatism is positively related to both the bargaining powers of customers and supplies. In robustness check, this paper divides our sample into high and low subsamples based on accounting conservatism. In Tables 6 and 7, the evidences are similar to those shown in Table 3 for the high accounting conservatism subsample, supporting H1a, H1b, H2a, H2b, H3a, and H3b.

Table 6. Bargaining power, capital expenditure and accrual-based earnings management

\begin{tabular}{|c|c|c|c|c|c|c|}
\hline \multicolumn{7}{|c|}{$\begin{aligned} \mathrm{EM}_{i t} & =a_{0}+a_{1} \text { CapitalExp }_{i t}+a_{2} \text { CusBarPow }_{i t}+a_{3} \text { CapitalExp }_{i t} \text { CusBarPow }_{i t}+a_{4} \text { MB }_{i t} \\
& +a_{5} \text { CFOStd }_{i t}+a_{6} \text { Leverage }_{i t}+a_{7} \text { Dividend }_{i t}+a_{8} \text { Default }_{i t}+a_{9} \text { OCF }_{i t}+\text { Industry }\end{aligned}$} \\
\hline & \multicolumn{2}{|c|}{ (High conservatism sample) } & \multicolumn{4}{|c|}{ (Low conservatism sample) } \\
\hline & $5 \%$ of sales & $10 \%$ of sales & HHI & $5 \%$ of sales & $10 \%$ of sales & HHI \\
\hline \multirow[t]{2}{*}{ CapitalExp } & -0.040 & 0.035 & 0.080 & 0.059 & 0.009 & -0.018 \\
\hline & $(0.160)$ & $(0.101)$ & $(0.010)$ & $(0.073)$ & $(0.734)$ & $(0.572)$ \\
\hline \multirow[t]{2}{*}{ CusBarPow } & 0.002 & 0.004 & 0.027 & 0.001 & 0.003 & 0.031 \\
\hline & $(0.260)$ & $(0.007)$ & $(0.004)$ & $(0.607)$ & $(0.067)$ & $(0.001)$ \\
\hline \multirow[t]{2}{*}{ CapitalExp*CusBarPow } & 0.020 & 0.016 & -0.948 & -0.0650 & -0.007 & 0.347 \\
\hline & $(0.520)$ & $(0.547)$ & $(0.000)$ & $(0.065)$ & $(0.805)$ & $(0.132)$ \\
\hline \multirow[t]{2}{*}{ MB } & 0.014 & 0.014 & 0.015 & 0.013 & 0.013 & 0.014 \\
\hline & $(0.000)$ & $(0.000)$ & $(0.000)$ & $(0.000)$ & $(0.000)$ & $(0.000)$ \\
\hline \multirow[t]{2}{*}{ CFOStd } & 0.089 & 0.088 & 0.123 & 0.124 & 0.124 & 0.117 \\
\hline & $(0.000)$ & $(0.000)$ & $(0.000)$ & $(0.000)$ & $(0.000)$ & $(0.000)$ \\
\hline \multirow[t]{2}{*}{ Leverage } & -0.018 & -0.02 & -0.021 & -0.008 & -0.008 & -0.032 \\
\hline & $(0.000)$ & $(0.000)$ & $(0.001)$ & $(0.025)$ & $(0.028)$ & $(0.000)$ \\
\hline \multirow[t]{2}{*}{ Dividend } & -0.010 & -0.010 & -0.010 & -0.020 & -0.019 & -0.022 \\
\hline & $(0.000)$ & $(0.000)$ & $(0.000)$ & $(0.000)$ & $(0.000)$ & $(0.000)$ \\
\hline \multirow[t]{2}{*}{ DefaultR } & -0.018 & -0.019 & -0.020 & -0.017 & -0.017 & -0.013 \\
\hline & $(0.000)$ & $(0.000)$ & $(0.000)$ & $(0.000)$ & $(0.000)$ & $(0.000)$ \\
\hline \multirow[t]{2}{*}{ OCF } & -0.083 & -0.083 & -0.070 & -0.051 & -0.051 & -0.045 \\
\hline & $(0.000)$ & $(0.000)$ & $(0.000)$ & $(0.000)$ & $(0.000)$ & $(0.000)$ \\
\hline \multirow[t]{2}{*}{ Intercept } & 2.578 & 2.651 & 9.250 & 2.542 & 2.507 & 8.654 \\
\hline & $(0.000)$ & $(0.000)$ & $(0.000)$ & $(0.000)$ & $(0.000)$ & $(0.042)$ \\
\hline Year and Industry & Included & Included & Included & Included & Included & Included \\
\hline No. of observations & 9578 & 9578 & 2580 & 9579 & 9579 & 2579 \\
\hline $\mathrm{R}^{2}$ & 0.167 & 0.167 & 0.2021 & 0.156 & 0.156 & 0.163 \\
\hline F value & 174.90 & 175.65 & 60.37 & 161.57 & 161.48 & 46.46 \\
\hline ( $p$ value) & $(0.000)$ & $(0.000)$ & $(0.000)$ & $(0.000)$ & $(0.000)$ & $(0.000)$ \\
\hline
\end{tabular}

Variable Definitions: EM denotes accrual-based earnings management. CapitalExp denotes capital expenditure. CusBarPow $5 \%$ of sales denotes the bargaining power of major customers, which is measured by the purchases of major customers that are larger than 5\% of the firm's total sales (as the supplier). CusBarPow 10\% of sales denotes the bargaining power of major customers, which is measured by the purchases of major customers that are larger than $10 \%$ of the firm's total sales (as the supplier). CusBarPow HHI denotes the bargaining power of major customers, which is measured by HHI. MB denotes market to book ratio. CFOStd denotes the volatility of operating cash flows. Leverage denotes financial leverage. Dividend denotes cash dividends. DefaultR denotes default risk. OCF denotes operating cash flows. P-values are reported beneath the coefficient estimates in parentheses. 
Table 7. Bargaining power, capital expenditure and real activities earnings management

\begin{tabular}{|c|c|c|c|c|c|c|}
\hline \multicolumn{7}{|c|}{$\begin{aligned} \text { EM }_{i t} & =a_{0}+a_{1} \text { CapitalExp }_{i t}+a_{2} \text { CusBarPow }_{i t}+a_{3} \text { CapitalExp }_{i t} \text { CusBarPow }_{i t}+a_{4} M B_{i t} \\
& +a_{5} \text { CFOStd }_{i t}+a_{6} \text { Leverage }_{i t}+a_{7} \text { Dividend }_{i t}+a_{8} \text { Default }_{i t}+a_{9} \text { OCF }_{i t}+\text { Industry }+ \text { Year }+e_{i t}\end{aligned}$} \\
\hline & \multicolumn{2}{|c|}{ (High conservatism sample) } & \multicolumn{4}{|c|}{ (Low conservatism sample) } \\
\hline & $5 \%$ of sales & $10 \%$ of sales & HHI & $5 \%$ of sales & $10 \%$ of sales & HHI \\
\hline \multirow[t]{2}{*}{ CapitalExp } & 0.747 & 0.564 & 0.258 & -0.246 & -0.157 & -0.206 \\
\hline & $(0.000)$ & $(0.000)$ & $(0.011)$ & $(0.010)$ & $(0.034)$ & $(0.028)$ \\
\hline \multirow[t]{2}{*}{ CusBarPow } & 0.004 & 0.007 & 0.067 & -0.013 & -0.012 & 0.094 \\
\hline & $(0.457)$ & $(0.089)$ & $(0.030)$ & $(0.013)$ & $(0.007)$ & $(0.001)$ \\
\hline \multirow[t]{2}{*}{ CapitalExp*CusBarPow } & -0.546 & -0.398 & 0.024 & 0.084 & -0.023 & -0.375 \\
\hline & $(0.000)$ & $(0.000)$ & $(0.964)$ & $(0.413)$ & $(0.782)$ & $(0.581)$ \\
\hline \multirow[t]{2}{*}{ MB } & -0.061 & -0.061 & -0.056 & -0.056 & -0.055 & -0.070 \\
\hline & $(0.000)$ & $(0.000)$ & $(0.000)$ & $(0.000)$ & $(0.000)$ & $(0.000)$ \\
\hline \multirow[t]{2}{*}{ CFOStd } & 0.165 & 0.163 & 0.133 & 0.026 & 0.028 & 0.126 \\
\hline & $(0.000)$ & $(0.000)$ & $(0.007)$ & $(0.315)$ & $(0.272)$ & $(0.010)$ \\
\hline \multirow[t]{2}{*}{ Leverage } & 0.212 & 0.212 & 0.262 & 0.177 & 0.176 & 0.242 \\
\hline & $(0.000)$ & $(0.000)$ & $(0.000)$ & $(0.000)$ & $(0.000)$ & $(0.000)$ \\
\hline \multirow[t]{2}{*}{ Dividend } & -0.016 & -0.016 & 0.025 & 0.000 & -0.001 & -0.007 \\
\hline & $(0.000)$ & $(0.000)$ & $(0.006)$ & $(0.908)$ & $(0.844)$ & $(0.441)$ \\
\hline \multirow[t]{2}{*}{ DefaultR } & 0.007 & 0.006 & -0.009 & -0.002 & -0.002 & 0.019 \\
\hline & $(0.145)$ & $(0.179)$ & $(0.344)$ & $(0.624)$ & $(0.699)$ & $(0.030)$ \\
\hline \multirow[t]{2}{*}{$\mathrm{OCF}$} & -1.452 & -1.452 & -1.529 & -1.398 & -1.397 & -1.253 \\
\hline & $(0.000)$ & $(0.000)$ & $(0.000)$ & $(0.000)$ & $(0.000)$ & $(0.000)$ \\
\hline \multirow[t]{2}{*}{ Intercept } & 3.190 & 3.566 & -72.761 & 0.487 & 0.625 & -92.329 \\
\hline & $(0.110)$ & $(0.074)$ & $(0.000)$ & $(0.814)$ & $(0.762)$ & $(0.000)$ \\
\hline Year and Industry & Included & Included & Included & Included & Included & Included \\
\hline No. of observations & 9578 & 9578 & 2580 & 9579 & 9579 & 2579 \\
\hline $\mathrm{R}^{2}$ & 0.607 & 0.607 & 0.574 & 0.582 & 0.582 & 0.531 \\
\hline F value & 1347.41 & 1347.59 & 316.79 & 1214.87 & 1214.32 & 266.31 \\
\hline ( $\mathrm{p}$ value) & $(0.000)$ & $(0.000)$ & $(0.000)$ & $(0.000)$ & $(0.000)$ & $(0.000)$ \\
\hline
\end{tabular}

Variable Definitions: EM denotes real activities earnings management. CapitalExp denotes capital expenditure. CusBarPow $5 \%$ of sales denotes the bargaining power of major customers, which is measured by the purchases of major customers that are larger than 5\% of the firm's total sales (as the supplier). CusBarPow $10 \%$ of sales denotes the bargaining power of major customers, which is measured by the purchases of major customers that are larger than $10 \%$ of the firm's total sales (as the supplier). CusBarPow HHI denotes the bargaining power of major customers, which is measured by HHI. MB denotes market to book ratio. CFOStd denotes the volatility of operating cash flows. Leverage denotes financial leverage. Dividend denotes cash dividends. DefaultR denotes default risk. OCF denotes operating cash flows. P-values are reported beneath the coefficient estimates in parentheses.

\section{Conclusion}

This paper discusses the determinants of earnings management in the context of a company's relationships with its customers. We first examine whether the relationship with supplier (company) and customers affects the degree of earnings management of the company. Next, we analyze the effects of accrual-based and real activities earnings management on capital expenditure when the relationships with suppliers and customers are factored into the models. The majority of the literature addressing earnings management refers to discretionary or abnormal accruals as 
measurements, while few studies discuss real activities earnings management. This study considers both accrual-based earnings management and real activities earnings management. The bargaining power of customers is factored into models in an examination of the effects on earnings management as well as the intervening role of bargaining power between capital expenditure and earnings management.

When the bargaining power of major consumers is measured by the HHI index, the result is that the higher the capital expenditure, the greater the accrual-based earnings management. If the bargaining power of major customers is measured by the thresholds of $5 \%$ and $10 \%$ of sales percentage, the evidence is that the higher the capital expenditure, the greater the real activities earnings management. We also find that the stronger the bargaining power of major customers, the larger the accrual-based and real activities earnings management of the company.

The evidences also show that the bargaining power of major customers (HHI) will affect the relationship between capital expenditure and accrual-based earnings management of the company. The bargaining power of major customers (5\% or $10 \%$ thresholds of revenue contribution) affects the relationship between capital expenditure and real activities earnings management of the company. In other words, earnings management of the company is also affected by corporate financing policy, investment decisions, and bargaining power of major customers. The bargaining power of major customers plays an important role in the relationship between earning management and capital expenditure.

Finally, this study finds that the greater the real activities and accrual-based earnings management in previous periods, the higher capital expenditure becomes in the current period. However, the greater the accrual-based and real activities earnings management and the stronger the bargaining power of major customers in the previous period, the lower the capital expenditure in the current period. We also find that the higher the capital expenditure in the current period, the greater the accrual-based and real activities earnings management in the current period. Meanwhile, the bargaining power of major customers in the current period affects the relationship between capital expenditure and earnings management in the current period. That is, the determinants of earnings management include many factors, such as corporate financing, investment policies, and bargaining power of major customers.

\section{References}

Aboody, D., Hughes, J., \& Liu, J. (2005). Earnings quality, insider trading, and cost of capital. Journal of Accounting Research, 43(5), 651-673. http://dx.doi.org/10.1111/j.1475-679X.2005.00185.x

Ansari, A. \& Riasi, A. (2016). Modelling and evaluating customer loyalty using neural networks: Evidence from startup insurance companies. Future Business Journal, 2(1), 15-30. http://dx.doi.org/10.1016/j.fbj.2016.04.001

Ashbaugh-Skaife, H., Collins, D. W., Kinney, W. R., \& LaFond, R. (2009). The effect of SOX internal control deficiencies on firm risk and cost of equity. Journal of Accounting Research, 47(1), 1-43. http://dx.doi.org/10.1111/j.1475-679X.2008.00315.x

Badertscher, B. A., Collins, D. W., \& Lys, T. Z. (2012). Discretionary accounting choices and the predictive ability of accruals with respect to future cash flows. Journal of Accounting and Economics, 53(1-2), 330-352. http://dx.doi.org/10.1016/j.jacceco.2011.11.003

Banerjee, S., Dasgupta, S., \& Kim, Y. (2008). Buyer-supplier relationships and the stakeholder theory of capital structure. Journal of Finance, 63(5), 2507-2552. http://dx.doi.org/10.1111/j.1540-6261.2008.01403.x

Barton, J. (2001). Does the use of financial derivatives affect earnings management decisions? The Accounting Review, 76(1), 1-26. http://dx.doi.org/10.2308/accr.2001.76.1.1

Basu, S. (1997). The conservatism principle and the asymmetric timeliness of earnings. Journal of Accounting and Economics, 24(1), 3-37. http://dx.doi.org/10.1016/S0165-4101(97)00014-1

Basu, S. (2001). Discussion of "On the asymmetric recognition of good and bad news in France, Germany and the United Kingdom". Journal of Business Finance and Accounting, 28(9-10), 1333-1349. http://dx.doi.org/10.1111/1468-5957.00417

Biddle, G. C., \& Hilary, G. (2006). Accounting quality and firm-level capital investment. The Accounting Review, 81(5), 963-982. http://dx.doi.org/10.2308/accr.2006.81.5.963

Bowen, R., DuCharme, L., \& Shores, D. (1995). Stakeholders' implicit claims and accounting method choice. Journal of Accounting and Economics, 20(3), 255-295. http://dx.doi.org/10.1016/0165-4101(95)00404-1

Bushman, R. M., \& Smith, A. J. (2001). Financial accounting information and corporate governance. Journal of Accounting and Economics, 32(1-3), 237-333. http://dx.doi.org/10.1016/S0165-4101(01)00027-1 
Cohen, D. A., \& Zarowin, P. (2010). Accrual-based and real earnings management activities around seasoned equity offerings. Journal of Accounting and Economics, 50(1), 2-19. http://dx.doi.org/10.1016/j.jacceco.2010.01.002

Dhaliwal, D., Hogan, C., Trezevant, R., \& Wilkins, M. (2011). Internal control disclosures, monitoring, and the cost of debt. The Accounting Review, 86(4), 1131-1156. http://dx.doi.org/10.2308/accr-10043

Doyle, J. T., Ge, W., \& McVay, S. (2007). Accruals quality and internal control over financial reporting. The Accounting Review, 82(5), 1141-1170. http://dx.doi.org/10.2308/accr.2007.82.5.1141

DuCharme, L. L., Malatesta, P. H., \& Sefcik, S. E. (2004). Earnings management, stock issues, and shareholder lawsuits. Journal of Financial Economics, 71(1), 27-49. http://dx.doi.org/10.1016/S0304-405X(03)00182-X

Francis, J., LaFond, R., Olsson, P., \& Schipper, K. (2005). The market pricing of accruals quality. Journal of Accounting and Economics, 39(2), 295-327. http://dx.doi.org/10.1016/j.jacceco.2004.06.003

Graham, J. R., Harvey, C. R., \& Rajgopal, S. (2005). The economic implications of corporate financial reporting. Journal of Accounting and Economics, 40(1-3), 3-73. http://dx.doi.org/10.1016/j.jacceco.2005.01.002

Healy, P. M., \& Palepu, K. G. (2001). Information asymmetry, corporate disclosure, and the capital markets: A review of the empirical disclosure literature. Journal of Accounting and Economics, 31(1-3), 405-440. http://dx.doi.org/10.1016/S0165-4101(01)00018-0

Hui, K. W., Klasa, S., \& Yeung, P. E. (2012). Corporate suppliers and customers and accounting conservatism. Journal of Accounting and Economics, 53(1-2), 115-135. http://dx.doi.org/10.1016/j.jacceco.2011.11.007

Lambert, R., Leuz, C., \& Verrecchia, R. (2007). Accounting information, disclosure, and the cost of capital. Journal of Accounting Research, 45(2), 385-420. http://dx.doi.org/10.1111/j.1475-679X.2007.00238.x

Lin, S., Radhakrishnan, S., \& Su, L. (2006). Earnings management and guidance for meeting or beating analysts' earnings forecasts. Working Paper.

McNichols, M. F., \& Stubben, S. R. (2008). Does earnings management affect firms' investment decisions? The Accounting Review, 83(6), 1571-1603. http://dx.doi.org/10.2308/accr.2008.83.6.1571

Rajgopal, S., \& Venkatachalam, M. (2011). Financial reporting quality and idiosyncratic return volatility. Journal of Accounting and Economics, 51(1-2), 1-20. http://dx.doi.org/10.1016/j.jacceco.2010.06.001

Riasi, A. (2015). Barriers to international supply chain management in Iranian flower industry. Management Science Letters, 5(4), 363-368. http://dx.doi.org/10.5267/j.msl.2015.2.005

Roychowdhury, S. (2006). Earnings management through real activities manipulation. Journal of Accounting and Economics, 42(3), 335-370. http://dx.doi.org/10.1016/j.jacceco.2006.01.002

Subramanyam, K. R. (1996). The pricing of discretionary accruals. Journal of Accounting and Economics, 22(1-3), 249-281. http://dx.doi.org/10.1016/S0165-4101(96)00434-X

Watts, R. L., \& Zimmerman, J. L. (1986). Positive accounting theory. Prentice-Hall. Englewood Cliffs, NJ.

Watts, R. L. (2003a). Conservatism in accounting Part I: Explanations and implications. Accounting Horizons, 17(3), 207-221. http://dx.doi.org/10.2308/acch.2003.17.3.207

Watts, R. L. (2003b). Conservatism in accounting Part II: Evidence and research opportunities. Accounting Horizons, 17(4), 287-301. http://dx.doi.org/10.2308/acch.2003.17.4.287 